\title{
ANALISIS KEMAMPUAN MENULIS NARASI FIKSIONAL MELALUI KARTU KUNCI PADA SISWA SEKOLAH MENGENAH ATAS DI KULISUSU BARAT
}

\author{
Suhendi Syam \\ Program Studi Pendidikan Bahasa dan Sastra Indonesia \\ Universitas Muhammadiyah Buton \\ Jl. Betoambari No 36 Kota Baubau Sulawesi Tenggara \\ Email: Syamsuhendi @gmail.com
}

\begin{abstract}
Abstrak
Tujuan penelitian tindakan kelas ini adalah untuk mengetahui kemampuan siswa dalam menulis narasi fiksional melalui media kartu kunci pada siswa sekolah menengah atas di suatu sekolah negeri di Kulisusu Barat, Sulawesi Tenggara. Penelitian tindakan kelas ini dilakukan pada kelas X. Hasil penelitian ini menunjukkan bahwa pada pembelajaran menulis narasi fiksional partisipan lebih efektif menggunakan media kartu kunci dibandingkan dengan pembelajaran menulis narasi fiksional tanpa menggunakan media kartu kunci. Hal ini terbukti dari hasil paired samples test skor pra-tes dan pasca-tes yang menunjukkan hasil yang signifikan. Perubahan skor dari pra-tes ke pasca-tes lebih tinggi dengan peningkatan sebesar 10.46.
\end{abstract}

Kata Kunci: Kartu kunci; kemampuan; menulis; narasi fiksional

\begin{abstract}
The aim of this classroom action research is to find out the students' ability in writing fictional narratives using key card media as medium in learning in one of senior high schools in North Kulisusu, Southeast Sulawesi. The classroom action research focused on students of year ten. The findings of this study indicate that students' fictional narrative writing activity is more effective as mediated through key card media than learning to write fictional narratives without using the key card media. It is evident from the paired results of the pre-test and post-test scores indicating the result at significance level. The change in score from pre-test scores is higher with an increase of 10.46 .
\end{abstract}

Keywords: Ability; fictional narratives; key cards; writing 


\section{A. PENDAHULUAN}

Peningkatan kualitas pendidikan terus-menerus dilakukan untuk mewujudkan tujuan pembangunan nasional. Undang-Undang Sistem Pendidikan Nasional No. 20 Tahun 2003 mengemukakan bahwa pendidikan nasional berfungsi mengembangkan kemampuan dan membentuk watak serta peradaban bangsa yang bertujuan untuk mengembangkan potensi peserta didik agar menjadi manusia yang beriman dan bertaqwa kepada Tuhan Yang Maha Esa, berakhlak mulia, sehat, berilmu, cakap, kreatif, mandiri dan menjadi warga Negara yang demokratis serta bertanggungjawab. Untuk mewujudkan fungsi dan tujuan pendidikan nasional tersebut, pendidikan perlu dikelola dengan profesional.

Mutu pendidikan dapat terwujud jika proses pembelajaran diselenggarakan secara efektif, artinya proses belajar-mengajar (PBM) dapat berjalan secara lancar, terarah dan sesuai dengan tujuan pembelajaran. Banyak faktor yang mempengaruhi proses PBM tersebut, baik dari peserta didik maupun dari faktor-faktor lain seperti pengajar (guru), fasilitas, lingkungan serta media pendidikan. Siswa yang aktif dan kreatif didukung fasilitas serta guru yang menguasai materi dan strategi penyampaian secara efektif akan semakin menambah kualitas PBM.

Media pembelajaran sebagai salah satu sarana meningkatkan mutu pendidikan sangat penting dalam proses pembelajaran. Penggunaan media sebagai salah satu alat penunjang atau sarana untuk mempermudah pemahaman suatu materi pelajaran. Media juga dapat digunakan sebagai variasi dalam pembelajaran. Artinya, semakin konkret kegiatan belajar, semakin baik. Salah satu upaya mengkonkretkannya adalah melalui media.

Menurut Suryaman (2012), ada beberapa fungsi media di dalam pembelajaran bahasa Indonesia, antara lain pengalaman yang tak terbatas, menembus batas ruang kelas, meningkatkan interaksi langsung dengan cara tidak langsung, menanamkan konsep dasar yang benar, nyata, dan tepat, membangkitkan motivasi, membangkitkan minat baru, mengontrol kecepatan belajar, dan memberikan pengalaman menyeluruh.

Penelitian ini menggunakan media berupa kartu bergambar. Jika dilihat dari segi sifatnya, media ini tergolong kedalam media visual. Dalam penelitian ini, media yang digunakan adalah media kartu kunci. Pemilihan media kartu kunci sebagai media pembelajaran dapat memacu hasil menulis narasi yang maksimal dan mempermudah siswa dalam memahami bagaimana membuat narasi fiksional. Penggunaan media kartu kunci juga bisa memotivasi siswa agar terbiasa berpikir kreatif karena dalam pelaksanaannya siswa dibagi menjadi beberapa kelompok yang terdiri atas 3-4 anggota. Pembagian kelompok ini sebagai langkah suatu perlombaan menulis narasi fiksional. Media kartu yang digunakan terbuat dari kartu yang berisi sebuah 
kata kunci atau sebuah pokok permasalahan untuk memulai menulis narasi fiksional. Media tersebut memunculkan judul yang bervariasi dalam satu kelompok.

Dewasa ini, pendidikan di Indonesia, khususnya pendidikan dasar dan menengah menghadapi sejumlah masalah, termasuk hasil pembelajaran bahasa Indonesia yang secara implisit mengajarkan pembelajaran menulis pada salah satu aspek keterampilan berbahasa. Rendahnya keterampilan menulis siswa menurut Tompkins dan Hoskisson (dalam Siddik, 2010) tidak disebabkan oleh keterbatasan siswa, tetapi lebih kepada pendekatan yang dipergunakan oleh guru yang tidak mengarahkan siswa agar dapat menulis dengan baik.

Menulis merupakan suatu keterampilan berbahasa yang digunakan untuk berkomunikasi secara tidak langsung dengan orang lain. Tarigan (2011) menjelaskan menulis adalah kegiatan yang produktif dan ekspresif yang menuntut sang penulis untuk terampil dalam memanfaatkan grafologi, struktur bahasa, dan kosa kata. Lebih lanjut, ia menegaskan bahwa menulis merupakan kegiatan menurunkan atau melukiskan lambang-lambang grafik yang menggambarkan suatu bahasa yang dipahami oleh seseorang, sehingga orang-orang lain dapat membaca lambang-lambang grafik tersebut jika mereka memahami bahasa dan gambar grafik tersebut (Tarigan, 2011).

Karangan terdiri atas beberapa macam yaitu deskripsi, narasi, eksposisi, argumentasi, persuasi. Narasi, menurut Suparno dan Yunus (2009) adalah jenis karangan yang menceritakan proses kejadian suatu peristiwa. Tujuannya adalah memberikan gambaran yang sejelas-jelasnya kepada pembaca mengenai fase, langkah, urutan, atau rangkaian terjadinya sesuatu. Sedangkan Alwasilah dan Alwasilah (2010) menyatakan bahwa narasi berasal dari kata to narrate, yaitu bercerita. Cerita adalah rangkaian peristiwa atau kejadian secara kronologis, baik fakta maupun rekaan atau fiksi.

Narasi mencakup dua unsur dasar yaitu perbuatan atau tindakan yang terjadi dalam suatu rangkaian waktu. Utami, dkk (2011) mengatakan bahwa ide menulis narasi dapat diperoleh berdasarkan rekaan atau imajinasi dan berdasarkan kejadian sesungguhnya. Rekaan merupakan cerita fiktif berupa hal atau peristiwa yang tidak terjadi sesungguhnya. Tema, tokoh dan tempat terjadinya peristiwa hanya ada dalam angan-angan pengarang. Akan tetapi, jika berdasarkan kejadian sesungguhnya berarti peristiwa tersebut baik tema, tokoh dan tempat terjadinya peristiwa benar-benar nyata dan ada. Peristiwa tersebut benar-benar terjadi dan bukan khayalan atau imajinasi.

Keraf (2009) membedakan narasi menjadi dua, yaitu narasi ekspositoris dan sugestif. Narasi ekspositoris mempersoalkan tahap-tahap kejadian, rangkaian-rangkaian perbuatan kepada para pembaca atau pendengar. Sementara itu, narasi sugestif (Keraf, 2009) merupakan suatu rangkaian peristiwa yang disajikan sekian macam sehingga merangsang daya khayal 
para pembaca. Pembaca menarik suatu makna baru diluar apa yang diungkapkan secara eksplisit, yaitu sesuatu yang tersurat mengenai obyek atau subyek yang bergerak dan bertindak, sedangkan makna yang baru adalah sesuatu yang tersirat. Penjelasan Keraf (2009) mengenai perbedaan antara narasi ekspositoris dan narasi sugestif dipaparkan pada uraian di bawah ini.

Tabel 1. Perbedaan narasi ekspositoris dan narasi sugestif

\begin{tabular}{|c|c|}
\hline Narasi Ekspositori & Narasi Sugestif \\
\hline 1. Memperluas pengetahuan & $\begin{array}{l}\text { 1. Menyampaikan suatu makna atau suatu amanat } \\
\text { yang tersirat }\end{array}$ \\
\hline $\begin{array}{l}\text { 2. Menyampaikan informasi mengenai } \\
\text { suatu kejadian }\end{array}$ & 2. Menimbulkan daya khayal \\
\hline $\begin{array}{l}\text { 3. Didasarkan pada penalaran untuk } \\
\text { mencapai kesepakatan rasional }\end{array}$ & $\begin{array}{l}\text { 3. Penalaran hanya berfungsi sebagai alat untuk } \\
\text { menyampaikan makna, sehingga jika perlu } \\
\text { penalaran dapat dilanggar }\end{array}$ \\
\hline $\begin{array}{l}\text { 4. Bahasanya lebih condong ke bahasa } \\
\text { informatif dengan titik berat pada } \\
\text { penggunaan kata-kata denotatif }\end{array}$ & $\begin{array}{l}\text { 4. Bahasanya lebih condong kebahasa figuratif } \\
\text { dengan menitikberatkan penggunaan kata-kata } \\
\text { konotatif }\end{array}$ \\
\hline
\end{tabular}

Keraf, (2009) memaparkan bahwa sesuai dengan perbedaan antara narasi ekspositoris dan narasi sugestif, maka narasi dapat dibedakan atas bentuk narasi fiktif (fiksi) dan narasi non-fiktif (non-fiksi). Bentuk narasi fiksi atau narasi sugestif yang biasa dibicarakan dalam hubungan kesusastraan adalah roman, novel, cerpen, dan dongeng. Sedangkan narasi non-fiktif atau narasi ekspositoris adalah sejarah, biografi, dan auto biografi.

Nurgiyantoro (2012) mengemukakan bahwa secara teoritis, karya fiksi dapat dibedakan dengan karya non-fiksi, walaupun pembedaan tersebut tidak bersifat mutlak. Hal ini menyangkut unsur kebahasaan maupun unsurisi permasalahan yang dikemukakan, khususnya yang berkaitan dengan data faktual, dunia realitas. Jadi, narasi fiksional disebut juga narasi sugestif. Istilah narasi sugestif lebih sering digunakan dari pada narasi fiksi. Namun, dalam kajiannya narasi sugestif dan narasi fikisional memiliki arti yang sama. Fiksi merupakan karya sastra yang menceritakan sesuatu yang bersifat rekaan atau tidak sunguh-sungguh terjadi sehingga tidak perlu mencari kebenaran cerita di dalam dunia nyata.

Lebih lanjut, Nurgiyantoro (2012) menegaskan bahwa wujud lahiriah, wujud manifestasi sebuah karya fiksi dan sebuah teks naratif adalah bahasa. Analisis sebuah karya fiksi naratif perlu mengkaji tentang unsur intrinsiknya seperti peristiwa, plot, tokoh (penokohan), latar, tema, sudut pandang dan gaya bahasa. Langkah selanjutnya mengkaji koherensi dan kepaduan semua unsur cerita.

Suryaman (2012) mengemukakan bahwa secara bahasa, media pembelajaran dapat diartikan perantara atau pengantar. Sedangkan secara 
terminologis, media pembelajaran dapat diartikan sebagai seluruh perantara (dalam hal ini bahan atau alat) yang dapat dipakai untuk mencapai tujuan pembelajaran. Media pembelajaran yang diklasifikasikan dari segi sifatnya meliputi media audio, visual, dan audiovisual. Dari segi jangkauannya, ada media radio dan televisi serta film slide, film, dan video. Dari segi pemakaiannya, media dapat dikelompokkan kedalam media proyeksi dan bukan proyeksi (Suryaman, 2012:135).

Terdapat beberapa fungsi media di dalam pembelajaran bahasa Indonesia antaralain (Suryaman, 2012: 134), pengalaman yang terbatas, menembus batas ruang kelas, meningkatkan interaksi langsung dengan cara tidak langsung, menanamkan konsep dasar yang benar, nyata, dan tepat, membangkitkan motivasi, membangkitkan minat baru, mengontrol kecepatan belajar, dan memberikan pengalaman menyeluruh.

Penelitian ini menggunakan media berupa kartu bergambar. Jika dilihat dari segi sifatnya, media ini termasuk media visual. Kartu merupakan penyajian visual yang menggunakan titik-titik, garis-garis, gambar-gambar atau simbol-simbol visual yang lain dengan sedikit keterangan agar peserta belajar lebih jelas menerima yang dikomunikasikan. Dalam pembuatan kartu perlu diperhatikan ukuran lambang-lambang, gambar-gambar dibuat dengan teliti dan tepat, penggunaan warna akan dapat ciptakan kartu yang lebih baik. Namun demikian, disarankan agar pembuat kartu tidak terlalu banyak menggunakan warna. Kartu yang dibuat hendaknya mudah dibaca dan dipahami, serta hendaknya menyajikan suatu informasi yang utuh.

Karangan yang baik dapat dihasilkan dengan penggunaan media yang maksimal. Bagian penting bagi pencapaian tujuan pembelajaran bahasa pada umumnya meningkatkan keterampilan berbahasa Indonesia. Dari pemaparan diatas dapat disimpulkan bahwa kartu kunci dapat dijadikan sebagai media dalam pengajaran menulis karena dengan media kartu kunci dapat menggabungkan realitas dengan imajinasi mereka untuk membuat suatu narasi fiksional yangbaik.Dalam melakukan penilaian pada penelitian ini, model penilaian yang dikemukakan oleh Nurgiyantoro tersebut, diadaptasi dan disesuaikan dengan keterampilan menulis narasi fiksional. Berikut merupakan tabel penilaian yang telah diadaptasi.

Hal yang menjadi fokus pada penelitian ini adalah bagaimana media kartu kunci dapat meningkatkan kemampuan siswa dalam menulis narasi fiksional siswa kelas $X$ di SMA Negeri 1 Kulisusu Barat adan guna mendapatkan data yang objektif tentang peningkatan kemampuan siswa dalam menulis narasi fiksional melalui media kartu kunci. 
Tabel 2. Pedoman penilaian menulis narasi fiksional

\begin{tabular}{|c|c|c|c|c|c|}
\hline No & Aspek & Kriteria & $\begin{array}{c}\text { Skor } \\
\text { Maksimal }\end{array}$ & Skor & Indikator \\
\hline \multirow[t]{6}{*}{1} & \multirow[t]{6}{*}{ Isi } & \multirow{3}{*}{$\begin{array}{l}\text { Kesesuaian } \\
\text { cerita dengan } \\
\text { tema }\end{array}$} & \multirow[t]{3}{*}{15} & $14-15$ & B: isi cerita sesuai \\
\hline & & & & $12-13$ & $\begin{array}{l}\text { S: isi cerita kurang } \\
\text { sesuai }\end{array}$ \\
\hline & & & & $10-11$ & $\begin{array}{l}\mathrm{R} \text { : isi cerita tidak } \\
\text { sesuai }\end{array}$ \\
\hline & & \multirow[t]{3}{*}{$\begin{array}{l}\text { Kreativitas } \\
\text { pengembangan } \\
\text { cerita }\end{array}$} & \multirow[t]{3}{*}{15} & $14-15$ & $\begin{array}{l}\text { B: cerita } \\
\text { dikembangkan kreatif } \\
\text { tanpa keluar dari tema }\end{array}$ \\
\hline & & & & $12-13$ & $\begin{array}{l}\text { S: cerita } \\
\text { dikembangkan kurang } \\
\text { kreatif }\end{array}$ \\
\hline & & & & $10-11$ & $\begin{array}{l}\text { R: cerita } \\
\text { dikembangkan tidak } \\
\text { kreatif }\end{array}$ \\
\hline \multirow[t]{9}{*}{2} & \multirow{9}{*}{$\begin{array}{l}\text { Organisasi } \\
\text { dan } \\
\text { penyajian }\end{array}$} & \multirow{3}{*}{$\begin{array}{l}\text { Penyajian } \\
\text { alur, tokoh dan } \\
\text { setting }\end{array}$} & \multirow[t]{3}{*}{10} & $9-10$ & $\begin{array}{l}\text { B: Lengkap, jelas dan } \\
\text { menarik }\end{array}$ \\
\hline & & & & $7-8$ & $\begin{array}{l}\text { S: Lengkap, namun } \\
\text { kurang jelas dan } \\
\text { menarik }\end{array}$ \\
\hline & & & & $5-6$ & $\begin{array}{l}\text { R:Tidak lengkap, jelas } \\
\text { dan menarik }\end{array}$ \\
\hline & & \multirow{4}{*}{$\begin{array}{l}\text { Penyajian sudut } \\
\text { pandang, gaya } \\
\text { dan nada, serta } \\
\text { judul }\end{array}$} & \multirow[t]{4}{*}{10} & $9-10$ & $\begin{array}{l}\text { B: Sudut pandang } \\
\text { konsisten, gaya dan } \\
\text { nada serta judul }\end{array}$ \\
\hline & & & & $7-8$ & $\begin{array}{l}\text { Sangat jelas, baik dan } \\
\text { menarik }\end{array}$ \\
\hline & & & & $5-6$ & $\begin{array}{l}\text { S:Sudut pandang } \\
\text { konsisten, gaya } \\
\text { Dan nada serta judul } \\
\text { kurang Jelas dan } \\
\text { menarik }\end{array}$ \\
\hline & & & & & $\begin{array}{l}\text { R:Sudut pandang } \\
\text { tidak konsisten,Gaya } \\
\text { dan nada serta judul } \\
\text { tidak Jelas dan tidak } \\
\text { menarik }\end{array}$ \\
\hline & & \multirow[t]{2}{*}{$\begin{array}{l}\text { Kepaduan } \\
\text { unsur- } \\
\text { unsurcerita }\end{array}$} & \multirow[t]{2}{*}{10} & $9-10$ & $\begin{array}{l}\text { B: urutan ceritayang } \\
\text { disajikan membentuk } \\
\text { kepaduan cerita yang } \\
\text { sangat serasi dan } \\
\text { sangat menarik }\end{array}$ \\
\hline & & & & $7-8$ & $\begin{array}{l}\text { S: urutan cerita yang } \\
\text { Disajikan membentuk } \\
\text { kepaduan cerita yang }\end{array}$ \\
\hline
\end{tabular}


Penyajian urutan cerita secara logis

$$
\begin{aligned}
& \text { Penggunaan } \\
& \text { sarana retotika } \\
& \text { Penggunaan } \\
& \text { unsur } \\
& \text { leksikal dan } \\
& \text { gramatikal }
\end{aligned}
$$

4 Mekanik Keterpaduan paragraph

Penulisan
10

10

10

5

5 cukup serasi dan

menarik

5-6 R: urutan cerita yang disajikan membentuk kepaduan cerita yang kurang serasi dan menarik

9-10 B:urutan peristiwa yang disajikan sangat runtut dan logis sehingga mudah dipahami

7-8 S:urutan peristiwa yang disajikan cukup runtut dan logis

5-6 R:urutan peristiwa yangdisajikan Kurang runtut Dan logis sehingga sulit dipahami

9-10 B:sangat baik sehingga cerita Lebih menarik

7-8 S:cukup baik

5-6 R:kurang baik

9-10 B: pemilihan kata dan struktur kata tepat dan sesuai

7-8 S:pemilihan kata dan struktur kata tepat,namun kadang kurang sesuai

5-6 R:pemilihan kata dan struktur kata kurang tepat dan kurang sesuai

4-5 B: hubungan kalimat satu dengan yang lain sangat padu

2-3 S: hubungan kalimat satu dengan yang lain cukup padu

0-1 R: hubungan kalimat satu dengan yang lain kurang padu

4-5 B: penulisan tepat

2-3 S:penulisan tepat namun ada Sedikit kesalahan 
0-1 R: penulisan kurang tepat dan Banyak

kesalahan

Keterangan : B: baik, R: rendah, S: sedang

\section{B. METODE PENELITIAN}

Penelitian ini termasuk penelitian tindakan kelas (PTK). PTK ini mengikutsertakan perencanan yang bersifat reflektif mandiri secara terus menerus. Dengan demikian, proses pelaksanaan penelitian ini merupakan tahapan-tahapan yang siklusif. Sesuai prinsip dasar penelitian tindakan yang umum, setiap tahapan dan siklus selalu dilakukan secara partisipatoris dan kolaboratif antara peneliti dengan rekan guru yang serumpun di sekolah. Proses pelaksanaan tindakan dilakukan dalam empat tahapan secara berdaur ulang yang berawal dari perencanaan, lalu pelaksanaan, observasi, dan refleksi (Arikunto, 2009).

Mengingat penelitian ini menggunakan rancangan penelitian tindakan kelas (PTK) maka penelitian ini difokuskan pada satu kelas saja. Kelas yang dipilih adalah kelas X-B dengan jumlah 33 siswa. Kelas ini dipilih karena dari hasil penelitian awal, para siswa kurang dalam hal keterampilan menulis. Selain itu, siswa di kelas ini juga kurang semangat dalam belajar. Rata-rata nilai siswa masih di bawah KKM.

Kartu kunci dalam penelitian ini adalah suatu media visual yang terbuat dari kertas dengan tebal minimal $2 \mathrm{~mm}$, tinggi dan lebar minimal $3 \mathrm{~cm}$ berbentuk kartu yang menggunakan gambar-gambar dengan sedikit keterangan agar peserta didik belajar lebih jelas menerima yang dikomunikasikan. Kartu kunci ini berisi tentang suatu kata kunci untuk memulai menulis sebuah narasi fiksional. Dari kartu kunci ini, siswa mengembangkan kalimat sesuai imajinasinya masing-masing.

Gambar jam pada kartu sebagai pengingat pola urutan waktu untuk memulai menulis narasi fiksional. Dalam pengajaran media ini, angka 1-4 pada gambar pola kronologis disimbolkan sebagai acuan menulis karangan meliputi isi, organisasi dan penyajian, bahasa dan mekanik. Tulisan dan gambar pada kartu kunci mengacu pada topik permasalahan yang akan diturunkan menjadi sebuah judul karangan.

Objek penelitian ini adalah kemampuan menulis narasi fiksional melalui media kartu kunci pada siswa kelas X. Tempat PTK ini yaitu di SMA Negeri 1 Kulisusu Barat. 

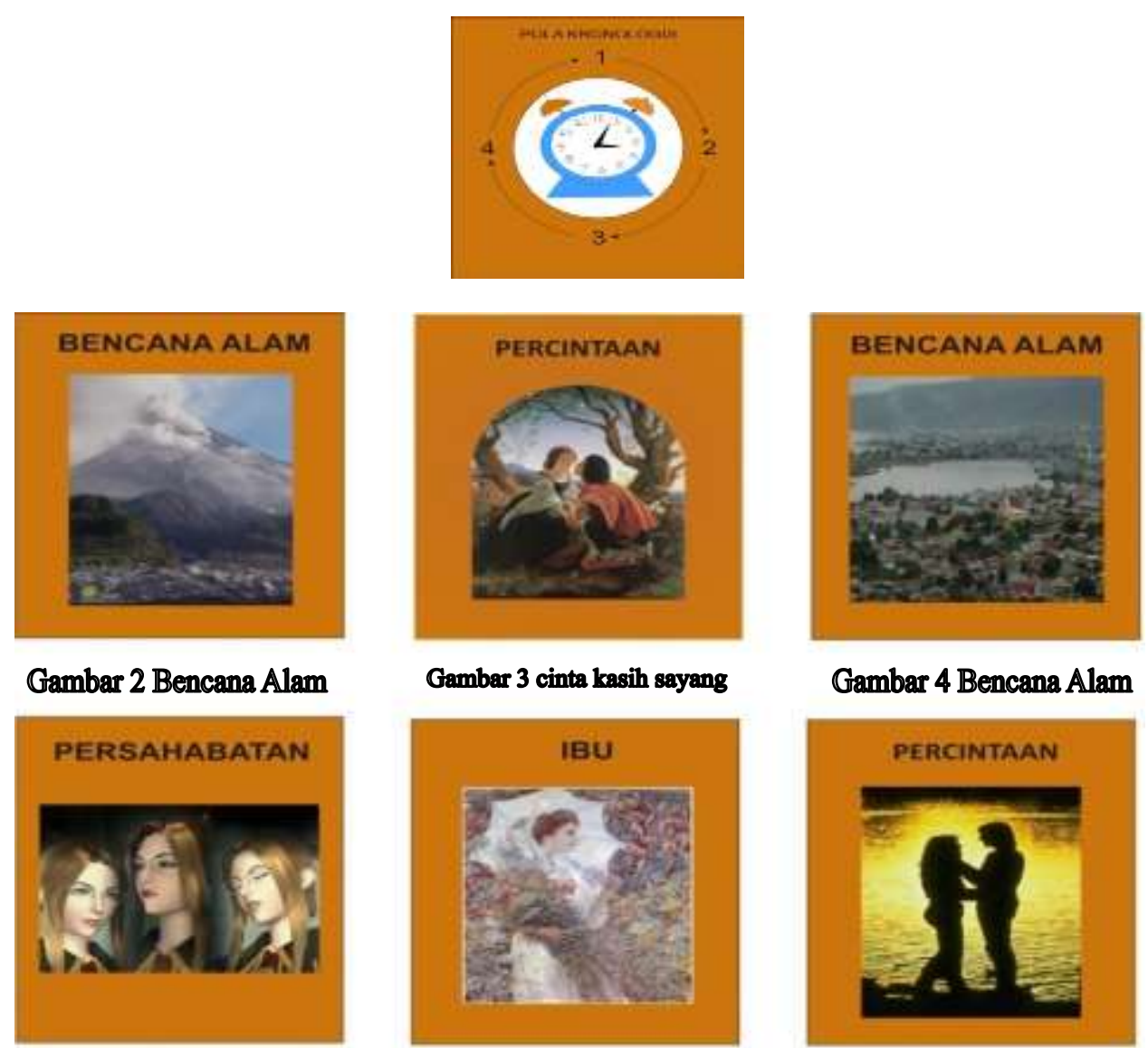

\section{Gambar 4 Bencana Alam}
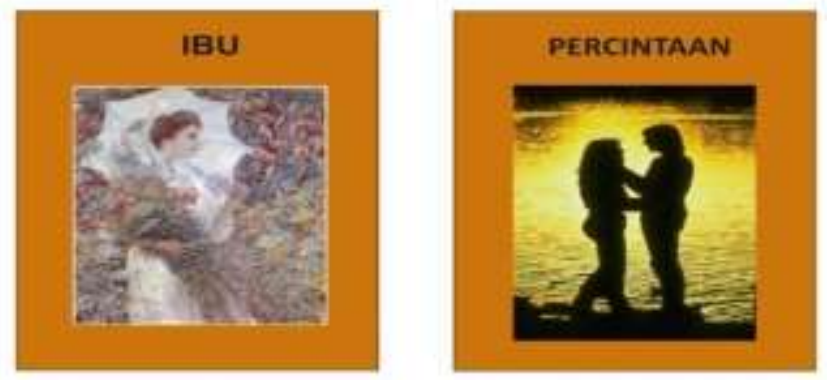

\section{Gambar 5 Persahabatan}

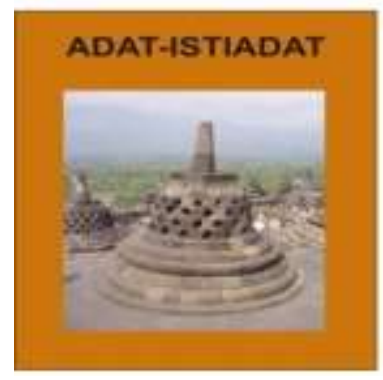

Gambar 8 Adat Istiadat

\section{Gambar 6 Kasih Sayang Ibu}

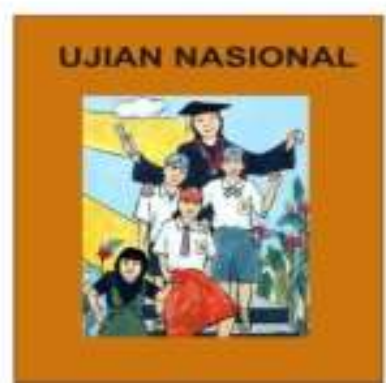

Gambar 9 Ujian Nasional
Gambar 7 Cinta Kasih Sayang

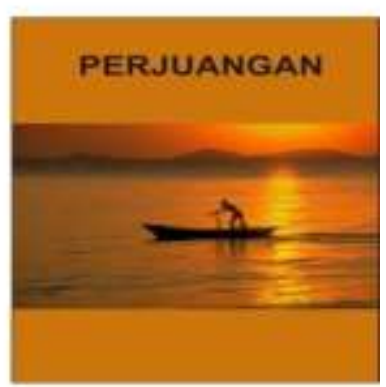

Gambar 10 Perjuangan

Gambar 1. Pola urutan waktu

\section{HASIL PENELITIAN}

Dari hasil pengamatan terhadap aktivitas siswa yang diperoleh pada pratindakan maka dilakukan refleksi. Berdasarkan hasil refleksi ini, diputuskan untuk mempertahankan hal-hal yang positif yang dapat 
mendukung pembelajaran dan merevisi hal-hal yang negatif yang menghambat proses pembelajaran.

\section{Deskripsi Data Prates Keterampilan Menulis Narasi Fiksional}

Pada tahap awal dilakukan prates dengan jumlah 33 siswa. Hasil prates yaitu diperoleh 80 skor tertinggi dan 60 skor terendah. Deskripsi perhitungan selengkapnya dapat dilihat pada kolom berikut.

Tabel 3. Distribusi frekuensi skor prates keterampilan menulis narasi fiksional

\begin{tabular}{rcccc}
\hline Skor & Frekuensi & Frekuensi $(\boldsymbol{\%})$ & $\begin{array}{c}\text { Frekuensi } \\
\text { Kumulatif }\end{array}$ & $\begin{array}{c}\text { Frekuensi } \\
\text { Kumulatif }(\boldsymbol{\%})\end{array}$ \\
\hline 60 & 3 & 9.1 & 9.1 & 9.1 \\
61 & 3 & 9.1 & 9.1 & 18.2 \\
62 & 1 & 3.0 & 3.0 & 21.2 \\
63 & 1 & 3.0 & 3.0 & 24.2 \\
64 & 1 & 3.0 & 3.0 & 27.3 \\
66 & 1 & 3.0 & 3.0 & 30.3 \\
67 & 1 & 3.0 & 3.0 & 33.3 \\
68 & 1 & 3.0 & 3.0 & 36.4 \\
69 & 2 & 6.1 & 6.1 & 42.4 \\
70 & 3 & 9.1 & 9.1 & 51.5 \\
71 & 4 & 12.1 & 12.1 & 63.6 \\
72 & 1 & 3.0 & 3.0 & 66.7 \\
73 & 2 & 6.1 & 6.1 & 72.7 \\
7 & 2 & 6.1 & 6.1 & 78.8 \\
75 & 1 & 3.0 & 3.0 & 81.8 \\
7 & 2 & 6.1 & 6.1 & 87.9 \\
7 & 1 & 3.0 & 3.0 & 90.9 \\
78 & 2 & 6.1 & 6.1 & 97.0 \\
80 & 1 & 3.0 & 3.0 & 100.0 \\
\hline Total & 33 siswa & $\mathbf{1 0 0 . 0}$ & $\mathbf{1 0 0 . 0}$ & \\
\hline
\end{tabular}

Berdasarkan tabel di atas, dapat diketahui bahwa kemampuan siswa masih relatif rendah. Ada beberapa temuan yang menonjol dan berpengaruh langsung terhadap peningkatan mutu pembelajaran narasi fiksional yang dapat menghambat peningkatan mutu pembelajaran narasi fiksional. Hal tersebut antara lain: a) kurangnya pengetahuan siswa tentang menulis narasi fiksional; b) siswa kesulitan merangkai dan menemukan kata yang cocok untuk menulis narasi fiksional; c) banyak siswa yang tidak mengiraukan penulisan huruf kapital pada awal kalimat dan penggunaan tanda titik pada akhir kalimat; d) siswa sangat jarang diberikan kesempatan mengembagkan kemampuan menulis; e) siswa lebih sering disuruh menghafal jenis-jenis karangan tanpa diminta mencoba menulis 
atau menyusun karangan; dan, f) pelajaran menulis membosankan bagi siswa.

Media kartu kunci merupakan salah satu media pembelajaran yang efektif digunakan dalam pembelajaran menulis narasi fiksional. Keefektifan media kartu kunci terlihat dari tahapan yang dilalui. Keefektifan media kartu kunci juga dapat dilihat dari segi hasil pembelajaran. Waktu yang digunakan untuk menghasilkan sebuah narasi fiksional fiksional juga lebih efektif. Hasil menulis narasi fiksional siswa bisa lebih bebas, kreatif dan mengembangkan imajinasinya sehingga tulisan menjadi lepas dan bebas sesuai keinginan mereka dengan memperhatikan kaidah penulisan yang baik dan benar.

Media pembelajaran kartu kunci dapat memberikan dampak positif terkait kemajuan keterampilan menulis narasi siswa. Hal ini dapat dilihat saat siswa melakukan evaluasi dalam pembelajarannya sendiri dengan menilai kelebihan dan kekurangan penerimaan materi yang didapatkan. Dari segi proses pembelajaran, guru memulai pembelajaran dengan bertanya tentang proses faktual dalam kehidupan sehari-hari yang dialami siswa. Guru membangkitkan minat siswa dengan mengaitkan materi narasi fiksional dengan pengalaman siswa. Melalui cara mendorong siswa mengingat kembali pengalaman sehari-hari yang berhubungan dengan tema yang dipilih, siswa akan mendapatkan banyak ide dan gambaran. Siswa menjadi lebih mudah terinspirasi dan memiliki kreativitas yang tinggi untuk memperoleh ide dalam menulis narasi fiksional.

Dalam proses penerimaan materi, siswa melewati tahap eksplorasi. Siswa membentuk kelompok-kelompok kecil untuk kemudian menilai contoh cerita yang diberikan oleh guru. Melalui proses tersebut, siswa mendiskusikan narasi fiksional yang telah didapatkan untuk dilakukan identifikasi jenis, perbedaan antara narasi fiksional dan ekspositoris, serta ciri-ciri narasi fiksional.

Melalui tahap penjelasan, siswa mencoba menjelaskan hasil temuan yang telah mereka dapatkan dan mereka mencocokkan dengan pemahaman dan penjelasan dari guru. Dalam tahap elaborasi, siswa menerapkan pengetahuan dan pemahaman yang telah didapatkan dengan menulis sebuah narasi fiksional. Melalui tahap evaluasi, siswa menilai kelebihan dan kekurangan penerimaan materi yang didapatkan dalam pembelajarannya sendiri.

Hasil menulis narasi lebih baik dilihat dari skor tiap aspek yang dinilai. Aspek-aspek tersebut meliputi isi, organisasi dan penyesuaian, bahasa dan mekanik. Melihat adanya kebermanfaatan dan keefektifan dari media kartu kunci, penelitian ini telah membuktikan bahwa media kartu kunci dapat digunakan sebagai bagian dari salah satu inovasi pembelajaran menulis narasi fiksional guna meningkatkan mutu pendidikan dan kualitas guru maupun peserta didik. 
Dari hasil tes menulis narasi fiksional akhir, skor tertinggi yang dicapai adalah 89 dan skor terendah adalah 65. Hasil perhitungan selengkapnya dapat dilihat pada tabel 4 berikut.

Tabel 4. Distribusi frekuensi skor pascates keterampilan menulis narasi fiksional

\begin{tabular}{ccccc}
\hline Skor & Frekuensi & Frekuensi (\%) & $\begin{array}{c}\text { Frekuensi } \\
\text { Kumulatif }\end{array}$ & $\begin{array}{c}\text { Frekuensi } \\
\text { Kumulatif (\%) }\end{array}$ \\
\hline 65 & 1 & 3.0 & 3.0 & 3.0 \\
66 & 1 & 3.0 & 3.0 & 6.1 \\
69 & 1 & 3.0 & 3.0 & 9.1 \\
70 & 3 & 9.1 & 9.1 & 18.2 \\
71 & 1 & 3.0 & 3.0 & 21.2 \\
73 & 2 & 6.1 & 6.1 & 27.3 \\
75 & 1 & 3.0 & 3.0 & 30.3 \\
76 & 3 & 9.1 & 9.1 & 39.4 \\
77 & 1 & 3.0 & 3.0 & 42.4 \\
78 & 1 & 3.0 & 3.0 & 45.5 \\
79 & 3 & 9.1 & 9.1 & 63.5 \\
80 & 3 & 9.1 & 9.1 & 69.7 \\
81 & 2 & 6.1 & 6.1 & 78.8 \\
82 & 3 & 9.1 & 9.1 & 81.8 \\
83 & 1 & 3.0 & 3.0 & 93.9 \\
84 & 4 & 12.1 & 12.1 & 100.0 \\
85 & 1 & 3.0 & 3.0 & \\
89 & 1 & 3.0 & 3.0 & \\
\hline Total & 33 & $\mathbf{1 0 0 . 0}$ & $\mathbf{1 0 0 . 0}$ & \\
\hline
\end{tabular}

Hasil penelitian yang telah dilakukan pada siswa kelas $\mathrm{X}$ ini menunjukkan adanya perubahan skor yang lebih tinggi. Perubahan skor ratarata dari tes awal dan tes akhir menunjukkan bahwa kartu kunci efektif dalam digunakan dalam pembelajaran menulis narasi fiksional. Penggunaan media kartu kunci merupakan salah satu alternatif bagi guru untuk mengajarkan pembelajaran menulis narasi fiksional agar siswa tidak merasa jenuh serta dapat memotivasi siswa.

Perubahan skor rata-rata prates ke pasca tes sebesar 8,636. Data prates keterampilan menulis narasi fiksional menunjukkan skor terendah 60 dan skor tertinggi 80. Perubahan skor rata-rata prates ke pasca tes sebesar 10,455. Data prates keterampilan menulis narasi fiksional menunjukkan skor terendah 58 dan skor tertinggi 80. Data pascates keterampilan menulis narasi fiksional menunjukkan bahwa skor terendah 71 dan skor tertinggi 90 . Perubahan tersebut terlihat ketika tes awal siswa belum menggunakan media kartu kunci sehingga nilainya masih rendah sedangkan pada tes kedua mereka sudah menggunakan media kartu kunci sehingga memengaruhi nilai siswa. 


\section{KESIMPULAN}

Temuan penelitian ini menunjukkan bahwa pembelajaran menulis narasi fiksional menggunakan media kartu kunci lebih efektif daripada pembelajaran menulis narasi fiksional tanpa menggunakan media kartu kunci. Temuan penelitian tersebut berimplikasi baik secara teoretis maupun secara praktis. Secara teoretis, temuan penelitian ini memberikan bukti secara ilmiah tentang keefektifan media kartu kunci dalam pembelajaran menulis narasi fiksional. Temuan dalam penelitian ini juga membuktikan bahwa media kartu kunci mengajak siswa untuk mengalami proses pembelajaran menulis narasi fiksional secara mandiri dan kreatif.

Salah satu hal yang menarik dari media kartu kunci adalah siswa belajar menganalisis karangan dan menuliskan ide, imajinasi, gambaran, serta perasaan yang didapat ke dalam bentuk narasi fiksional. Secara praktis, temuan ini menunjukkan bahwa proses pembelajaran menulis narasi fiksional menggunakan media kartu kunci lebih efektif dari pada pembelajaran menulis narasi fiksional tanpa media kartu kunci. Oleh karena itu, guna mendapatkan hasil keterampilan menulis narasi perlu menggunakan media kartu kunci. Pembelajaran menulis narasi fiksional siswa kelas $\mathrm{X}$ bisa lebih efektif melalui pemanfaatn media kartu kunci dalam pembelajaran dibandingkan dengan pembelajaran tanpa menggunakan media kartu kunci.

\section{E. DAFTAR PUSTAKA}

Alwasilah, A. C., \& Alwasilah, S. S. (2010). Pokoknya menulis. Bandung: Kiblat Buku Utama.

Arikunto, S. (2009). Prosedur penelitian tindakan kelas. Jakarta: Rineka Cipta.

Keraf, A. O. G. (2009). Keterampilan dasar menulis. Jakarta: Universitas Terbuka.

Keraf, A. O. G. (2011). Argumentasi dan narasi. Jakarta: Penerbit PT Gramedia.

Komala, Setiawan, \& Indihadi. (2018). Analisis pembelajaran menulis narasi berdasarkan kinerja guru sekolah dasar. Pedadidaktika, 5(2), 110118. 
Miftahul, G., dkk. (2017). Meningkatkan keterampilan menulis karangan narasi melalui model PWIM siswa kelas IV B SDN Ketib Kecamatan Sumedang Utara Kabupaten Sumedang. Pena Ilmiah, 2(1), 98-112.

Nurgiyantoro. (2012). Penelitian kualitatif. Jakarta: Universitas Terbuka.

Siddik, M. (2018). Peningkatan pembelajaran menulis karangan narasi melalui gambar berseri siswa sekolah dasar. Sebuah Kajian Teori dan Praktek Pendidikan, 27(1), 39-48.

Suparno, \& Yunus, M. (2009). Keterampilan dasar menulis. Jakarta: Universitas Terbuka.

Suryaman. (2012). Empat keterampilan berbahasa. Jakarta: Universitas Terbuka.

Tarigan, H. G. (2011). Menulis sebagai suatu keterampilan berbahasa. Bandung: Angkasa.

Tompkins, G. E., \& Hoskisson, K. (2010). Language art content and teaching strategies. New York: Macmillan.

Utami, S., dkk. (2011). Bahasa dan sastra Indonesia untuk SMA/MA kelas $X$. Jakarta: Pusat Perbukuan Departemen Pendidikan Nasional. 